Article

\title{
Buddhist Integration of Forest and Farm in Northern Thailand
}

\author{
Susan M. Darlington $(\mathbb{D}$
}

School of Critical Social Inquiry, Hampshire College, Amherst, MA 01007, USA; sdarlington@hampshire.edu

Received: 1 August 2019; Accepted: 9 September 2019; Published: 10 September 2019

\begin{abstract}
Usually seen as incompatible, forests and farms are integrated by Buddhist environmental activists in Thailand. Monks engaged in environmental conservation see the conditions of farmers' lives as related to how they treat the forests surrounding their farms. If farmers seek their livelihood through cash-cropping and contract farming, they see the forest as a material resource in terms of land for future farms. This attitude contributes to the rapid deforestation occurring across northern Thailand's mountainous region and a cycle of environmental degradation and economic struggle. Buddhist monks work with non-governmental organizations and sometimes state agents to encourage farmers to shift to integrated agriculture, growing a mix of food crops and raising animals mimicking ecological relations. The monks teach that the forest is part of this eco-system, as it supplies water and other natural resources and must be protected. This paper examines the work of Phrakhru Somkit Jaranathammo, a monk in Nan Province, Thailand, who promotes dhammic agriculture and engages a new interpretation of Right Livelihood, a basic Buddhist principle, to support and protect the well-being of both the forest and farmers.
\end{abstract}

Keywords: spiritual ecology; Buddhism; deforestation; Buddhist agriculture; Thailand

\section{Introduction}

Traveling across Nan Province in northern Thailand provides spectacular views of rolling mountains stretching into the distance. The problem is that one can see into the distance: few trees block the view. Nan wrestles with a severe problem of deforestation, even as forests are recovering in the rest of Thailand. Between 2000 and 2012, Nan's forests declined 33\% (Baicha 2016, p. 90). Forest cover in Thailand overall increased by $31-33 \%$ in the same time frame (Trisurat et al. 2019, p. 2). Fields of feed corn dominate the landscape in Nan, yet the government declares $86 \%$ of the province as protected areas, national parks, and reserve land. Having no land title, farmers encroach into the protected forests to plant fast-growing maize, leaving the mountains bald and themselves often in debt.

Combating the problem of deforestation and its causes requires creativity, commitment, and morality. Phrakhru Somkit Jaranathammo, a Buddhist monk from Nan Province, brings an innovative approach to dealing with the impacts of deforestation on both the environment and the people who depend on it. Having grown up in Nan, Somkit experienced the changes in farmers' livelihoods that contributed to loss of the forests and its impacts. Learning from other activist monks, he turned to Buddhism to provide insights and actions for helping people cope with the changes. Buddhism, Somkit argues, offers a moral compass that enables people to live in harmony with the natural world and to care for themselves and their communities. 
The forest "is essentially a part of life," Somkit told me (interview, 6/27/2019). ${ }^{1}$ It provides water, soil, food, and knowledge for the people who care for it. The forest cannot be separated from human life, especially the agriculture of rural people who live in and around it. Buddhist teachings can encourage farmers to shift from the destructive production of maize to what he calls dhammic agriculture. As part of an informal Buddhist environmental movement in Thailand (Darlington 2012), Somkit uses Buddhism first to identify the root causes of the environmental problems-especially greed and ignorance- then to find creative solutions that integrate pragmatism and spirituality.

Somkit's concept of dhammic agriculture applies Buddhist principles together with scientific and economic practices to farming. Through honesty, tolerance, patience, and sharing-the four values the Buddha taught for householders (Gharavasa-dhamma in Pali) (Payutto 1985, p. 135)—farmers can shift from capitalist agriculture to dhammic agriculture. Somkit described his focus as "Do a little, gain a lot. Only produce good quality products" (interview 6/27/2019). He stresses an interpretation of Right Livelihood, part of the Noble Eightfold Path in Buddhism, that enables farmers to increase their income and their agency while caring for both the natural environment and their community.

Phrakhru Somkit's case illustrates how Buddhist spiritual ecology works on the ground, integrating Buddhist teachings, nature, and farmers' livelihoods. Yet his approach represents an innovative interpretation of Buddhism. It draws from the monk's relationship with the people in his community and his reputation as a monk who understands and cares for the people and the forest. First, the ways in which he interprets Buddhism and the problems causing and emerging from deforestation must be unpacked. Somkit collaborates with farmers to negotiate a political and economic environment that cannot be separated from the natural or spiritual contexts.

Leslie Sponsel (2019) defines spiritual ecology "as a vast, complex, diverse, and dynamic arena of intellectual and practical activities at the interfaces of religions and spiritualities with ecologies, environments, and environmentalisms." In this arena, activists engaging spiritual ecology as a means of dealing with environmental problems call for a radical transformation of the industrial capitalist societies underlying the rapid deterioration of the natural environment. Somkit challenges capitalist agriculture and its impacts on nature and farmers' lives. His approach is radical in how he integrates morality and pragmatism.

This paper examines Phrakhru Somkit's efforts to deal with the impacts of deforestation on the people of his village and the surrounding area. The monk continually reassesses both the problems and how Buddhism and social and political factors can be used to find solutions. He ultimately sees both the causes of deforestation-including economics and politics-and the potential solutions as moral issues. His case sheds light on both the potential and the challenges of integrating Buddhism and environmentalism. Somkit's concept of dhammic agriculture offers a new approach to how farmers can earn a comfortable living in moral terms. The problem of deforestation provides a focus for this intersection.

\section{Spiritual Ecology in Thai Buddhism}

During the twentieth century, Thais began to see forests and land as material goods rather than part of the larger ecosystem upon which humans and all life depend. Prime Minister Field Marshall Sarit Thanarat established new economic goals in the 1960s that contributed significantly to this process, especially emphasizing industrial agriculture for export. Multi-national corporations moved in, buying agricultural land to create expansive, single-crop plantations ((Darlington 2012, pp. 102-3; Lohmann 1993, p. 205); for more on the complexities of development and environment, see (Rigg 1995; Trébuil 1995)). In search of a more comfortable life and encouraged by the government, many farmers shifted from subsistence farming and small-scale production into cash-cropping and contract farming.

1 As a public figure, Phrakhru Somkit Jaranathammo and his work are well known. He gave me permission to use his name at the beginning of the interview. 
These shifts required more agricultural land, leading farmers and companies to encroach into the nation's forests.

A few Buddhist monks saw these changes in the rural landscape as a moral crisis. They began to draw from Buddhist principles to understand the crisis and propose new ways forward. They used the three roots causes of suffering in Buddhism-desire, anger, and delusion-to analyze the emerging social and environmental problems. Concepts of interdependence, non-self, impermanence, and the four sublime virtues (compassion, loving-kindness, sympathetic joy, and equanimity) provided new approaches to guiding farmers into rethinking their relationship with nature, especially the ways in which they use the forest. These interpretations form what I consider the "spiritual ecology" of the Thai Buddhist monks engaged in environmental conservation work through working with farmers on a small scale to address the challenges of the industrial agricultural system and its capitalist roots.

Spiritual ecology for these monks entails drawing from Buddhist teachings to analyze the roots of the problems facing the farmers and the natural environment upon which they depend. They argue that the shift from subsistence farming to export and industrial agriculture reflects a growing greed among farmers, the government, and corporations alike, driven by material ambitions. Money rather than food became the goal. Concerns for the well-being of farmers and the land diminished as corporations expanded their plantations to grow products for the global market. Deforestation increased dramatically. Many village farmers, seeking more income, sold their land and moved into contract farming, often leading to economic insecurities and communal disruptions. Somkit believes that in their effort to improve their lives, farmers began to "only appreciate the forest for its monetary value.... The forest has been turned into wooden products, into beds and the couch on which we sit. This furniture becomes part of the way we enhance our status... The forest becomes just a commodity" (interview 6/27/2019).

Agro-chemical companies encouraged the expansion of agricultural land. They provided farmers with seeds, fertilizers, herbicides, and pesticides often as loans to be repaid at harvest. In Nan Province, feed corn was the primary crop supported by the companies. Seed corporations set strict standards for the quality of the produce they would buy from farmers to whom they lent seeds and fertilizers. If farmers could not meet these standards, they slipped into severe debt. This debt created a cyclical process as farmers again cut the forest in search of greater returns. Community norms for using forest resources and access to land were often thwarted as farmers sought their own gain.

According to these monks, this cycle of debt, deforestation, and selfishness lay on a firm grounding of delusion, the third root cause of suffering in Buddhism. Farmers bought into what the government and seed companies told them about the benefits of cash-cropping. They believed that having more material goods leads to happiness and success. Somkit describes this process as the result of delusion. "People don't understand. The problem is the power [of agro-chemical companies] and money combined with the use of [villagers'] ignorance ... to obscure people's vision." Corporations told farmers that if "your crops are not growing well, you must use fertilizers. If there are weeds, you must use herbicides. They don't teach people that if they use these [chemicals], there will be consequences" $(6 / 27 / 2019)$.

The monks saw the growing debt as creating deeper dissatisfaction, problems, and social conflict. Beyond the village, continual deforestation degraded and destroyed natural resources. Deforestation threatens watersheds and biodiversity, lessening critical resources for the village and forest alike. Without trees, soil eroded, carrying chemicals from fertilizers and herbicides into waterways. Annual flooding increased, alternating with more severe droughts in the dry season. The environmental problems exacerbated the difficulties of farming in the mountains. Villagers had greater difficulties making a livelihood despite their efforts and the promises of the corporations and government.

Environmental monks interpreted the roots of these problems as lying in the greed, anger, and delusion of people across society. They therefore began to look for ways to help people out of the cycle of debt and social and environmental destruction. They turned to Buddhist principles and practices to motivate change in the farmers' behavior. 
These Buddhist monks began working with non-government organizations (NGOs) to find alternatives to this process. They introduced alternative agricultural practices in the form of integrated or mixed agriculture (Darlington 2012). Through diversified cultivation of crops and animals in a way that mimics nature, integrated agriculture helps farmers move towards greater self-reliance. Counter to the argument of Thailand's agrarian myth (Dayley 2011), these methods do not aim to return to an idealized past of self-sufficiency and independence (a past that probably never fully existed) but to give farmers more control over their livelihoods.

What makes this response of Buddhist monks and activities a form of spiritual ecology? The question could be asked: what even makes this response Buddhist? Key is the explanation of greed as the underlying cause of this cycle of debt and environmental damage. The crisis is the result of spiritual and moral loss, as the people driving it - from the corporations to the government to many individual farmers-seem to care more for their own accumulation of goods, money, and the commodification of the forest than the well-being of other people or nature.

Buddhist monks help farmers make spiritual progress through reframing the causes of the environmental and economic problems they face and supporting alternative ways of living in line with Buddhist ethics. The ultimate goal of Buddhism is to escape the cycle of rebirth and suffering (achieving Awakening). This goal is soteriological, focused on a future life-or lack of rebirth—rather than more mundane, worldly problems. Yet most lay Buddhists are householders, not renunciants as the monks are. They do not actively think about achieving Awakening. They are concerned with getting through daily life, being able to feed their families, and having enough to live (maybe even comfortably). As the revered abbot in Chiang Mai, Luang Pu Chan Kusalo, used to say, people are not going to practice meditation if they are worried about how to feed their children (Darlington 2012, pp. 114-20). Therefore, some Thai Buddhist monks see it as their responsibility to assist people in finding both pragmatic and spiritual solutions to these problems. For them, the forests and people's livelihoods intersect in creating a moral society.

Forests play a role for Buddhist monks as a place for meditation and overcoming obstacles to spiritual progress. They are also a key resource for farmers in northern Thailand, providing water, wood, and land (among other resources). These monks reframe the forest in Buddhist terms, teaching practical aspects of Buddhist principles while helping farmers overcome the obstacles that lead them to cut the forests in search of material benefits.

Phrakhru Somkit emphasizes Right Livelihood. In undertaking Right Livelihood, farmers engage in the following actions while earning a living: farming with compassion; enacting loving kindness; taking care of the environment to include the land, water, animals, and other aspects of nature; taking care of one's family; taking care of the community; and taking care of the temple. These actions contribute to building Right Livelihood in the modern context. A key aspect of Somkit's interpretation of Right Livelihood involves caring for the forest rather than destroying it, a concept found in many aspects of Buddhist history.

\section{Forests in Buddhist and Thai History}

The Buddha's life was intimately linked with the forest. He was born, achieved Awakening, established monasteries, and passed away (parinibbana), all in the forest. His first sermon occurred in a deer park outside of the small town of Sarnath, India. The stories of the Buddha's close connections with the forest highlight the value of the forest in Buddhist teachings and practice (Chatsumarn 1998), even as much of his life was spent in cities and with lords and kings.

As with any religion, interpretations of the history, myths, and teachings enable practitioners and scholars to frame the religion in support of pressing issues (Gottlieb 2006; Queen 1996). Environmentalism is one such issue. Seeing environmental destruction and climate change in terms of a moral crisis, religious activists can provide a basis for analysis and shaping behavior towards a solution. For Buddhist environmentalists, this process begins with the Buddha's life and the forest (Chatsumarn 1998; Tucker and Williams 1997). 
Forests became crucial in early Buddhism as a place of retreat and escape from the pressures and ills of society. Buddhism emerged in India during a time of relative urbanization. As populations grew, cities became the centers of society. Kingdoms and republics vied for control of different regions. The rural areas surrounding cities provided food and resources, while the forests and more remote areas remained as "wild" and "uncivilized" (Ling 1973). Monks and nuns lived in forest communities to benefit from the quiet as they concentrated on their spiritual progress. The forest became a teacher, challenging practitioners to live in isolation and simplicity. In both ancient India and Thai society into the 20th century, the forest was also seen as dangerous (Kemp 1988; Stott 1991). Bandits, wild animals, ghosts, and spirits forced monks to establish equanimity and loving-kindness as well as learning to conquer fear and connection to self (Kamala 1997).

These elements of the role of the forest in Buddhism formed the basis for the practice of dhutanga (Pali) in Theravada Buddhist societies. Known as the forest monk tradition, this practice spread across Buddhist Sri Lanka and Southeast Asia. Dhutanga entailed individual monks emphasizing meditation and ascetic practices, including wandering in the forest, in order to intensify concentration and spiritual progress.

The forest monk tradition became a revered practice in Thai Buddhism. Renowned forest monks emerged, establishing lineages for their practice. These monks, such as Achan Man and Achan Cha, were seen as exemplars of Buddhist practice, drawing disciples from across the nation. Yet, as with the Buddha himself, forest monks remained connected with the hierarchies of the state and what became state Buddhism in the twentieth century (Kamala 1997; Taylor 1993).

Tiyavanich Kamala (1997) documents the process of how influential forest monks were used by the state in Bangkok to extend its influence and power into the peripheral and border areas of the nation during the first half of the twentieth century. Because of their reputations as sources of spiritual power and religious merit, forest monks commanded the respect and reverence of rural villagers. Initially, they practiced distinct regional forms of Buddhism, focused on meditation and austerities. The state authorities in Bangkok pushed them to teach Buddhist practice grounded in the Pali scriptures, homogenizing religious concepts and rituals. The Bangkok government saw localized forms of Buddhism as supporting the diverse principalities and ruling families across the land, often opposed to Bangkok's authority.

Key to my discussion of Buddhist concepts of forests, the government discouraged reverence of local spirits, especially the tutelar "lords of the land," in northern Thailand (Shalardchai 1984). These spiritual lords long held sway over the forest and land for local people. Farmers requested their permission before using forest resources, clearing land, or establishing farms. Spiritual leaders introduced anyone new in the area to the local spirit lords or risked illness or accident indicating the spirit's dissatisfaction. For rural people, spirits and the teachings of Buddhism co-existed. Spirits-such as the lords of the land or Mae Thoranee (Mother Earth) — guided behavior in the mundane aspects of life, including farming and family life. Phrakhru Somkit connects these spirits directly with an agricultural lifestyle. "According to local wisdom," he said, "good soil is protected by a beneficent spirit, Mae Thoranee, goddess of earth.... Good water is protected by the water goddess, Phramae Khong Kha" (interview 6/27/2019). The role of humans in these relations, he states, is to venerate these spirits and care for the natural resources they protect.

Limiting local religious concepts and practices gave the government in Bangkok greater control of the rural people and their land. Kamala (1997) lays out a chronology of the state's policies towards the forest that impacted how rural people and Buddhism interacted with and used the forest. These changes similarly affected farming practices and the conditions of the natural environment. The historical 
periods Kamala outlines are: (1) the "Forest-Community Period," prior to 1957; (2) the "Forest-Invasion Period," from 1957 to 1988; and (3) the "Forest-Closure Period," from 1989 to the present. ${ }^{2}$

During the Forest-Community Period, people followed regional and local practices and lived relatively isolated from the Bangkok government's influence. They used natural resources surrounding villages as they needed. With a low population density, people had a minimal impact on the environment. Villages had their own Buddhist temples with local monks in residence, providing spiritual and communal guidance. Forest monks, especially in the North and Northeast, roamed the countryside, interacting with villagers as they encountered them or needed support (Kamala 1997).

The Forest-Invasion Period began after a coup brought Field Marshall Sarit Thanarat and the military into power in 1957. As prime minister, Sarit implemented economic policies that pushed Thailand into the global economy, based on industry and export agriculture (Lohmann 1993, p. 205). The fertile regions in the nation's lowlands became sites of expansive mono-crop plantations. Multi-national seed companies benefited from both large plantations of crops and the establishment of contract farming - selling seeds and lending fertilizers and herbicides to small-scale farmers to produce crops and seeds. Roads built by the military in pursuit of Communist insurgents opened remote forested areas. Due to population pressures and the search for new lands, farmers from the lowlands followed the roads, expanding their fields into the forests. At the same time, small-scale farmers were either being bought out or pushed into debt through contract farming. They also sought more land through clearing forests (Kamala 1997, pp. 226-51). In northern Thailand in particular, a rapid process of deforestation began.

\section{Deforestation}

Thailand has long had a high rate of deforestation. According to official government documents, forest cover declined from 53.3\% of the nation's area in 1961 (just as Sarit introduced his policy of agricultural intensification) to $25.1 \%$ in 1999 . Forest activists, non-governmental organizations, and environmentalists disagree with these figures based on definitions of forest cover, arguing that the state includes plantation forests, not only natural forests. Some claim forest cover went as low as $15 \%$ of the country's area (Lohmann 1993, p. 200). With an emphasis on protecting the forest and reforestation efforts by both the state and environmentalists, the amount of forest cover increased and stabilized between 2000 and 2016 at 31-33\% (Trisurat et al. 2019, p. 2). Over time, however, the loss of natural forests has been severe, even with reforestation and regrowth in the early 21st century.

Nan Province faces among the worst deforestation in the nation today, illustrating the economic and environmental challenges rural farmers face even as the state attempts to protect the forests. Although natural forest covered $41.5 \%$ of Nan in 2012, this amount represents a loss of $33 \%$ of the province's natural forest since 2009 (Baicha 2016, p. 90). Nan is also one of the most mountainous regions in the country, with only a small stretch of lowland area following the Nan River from north to south through the center of the province. Most of its population of 478,000 (in 2013; Baicha 2016, p. 88) live in the lowlands, resulting in low population density across the province. The loss of forests in Nan means the mountains are being laid bare, creating additional problems of soil erosion, flooding, drought, and loss of biodiversity.

Concurrent with the deforestation, expansion of cultivated land occurred. According to Trisurat et al. (2019, p. 650), land used for agriculture doubled in Nan from 16\% of the provincial GDP in 2000 to $32 \%$ in 2016.

While the causes and impacts of deforestation remain complex (Forsyth 2006; Forsyth and Walker 2008), shifting forms of agricultural production played a key role is exacerbating the problems. The rise of permanent agriculture, cash- and mono-cropping, and contract farming occurred

2 Kamala's book was published in 1997, but I argue that the Forest-Closure Period continues today, even as some changes are occurring. 
simultaneously with increased deforestation. Farmers, aware that their lands were less productive and water less available, turned to local leaders, including monks, for guidance. Government agents and agro-chemical corporations advised increased production of cash crops to provide more income. The rising price of feed corn contributed to farmers in Nan planting more maize, clearing more forested areas in the process.

A handful of local monks envisioned a different approach, one that they hoped would help villagers focus more on ethical aspects of farming while protecting the remaining forests. They aimed to move farmers away from what they saw as a focus on materialism and the commodification of nature to emphasize a form of sustainability that cares for both the villagers' lives and the condition of the forest. ${ }^{3}$ Together with local non-governmental organizations (NGOs), these monks encouraged and supported farmers to shift from cash-cropping and contract agriculture to integrated agriculture.

Integrated agriculture (kaseet phasom phasaam in Thai) consciously entails mimicking nature. Plants that support each other are planted together, such as nitrogen-providing peas with plants that need nitrogen to grow well. Fish are raised in the water of rice paddy fields. Chickens and pigs are allowed to run freely around the vegetables, routing out weeds and eating insects while fertilizing the ground at the same time. Plants and animals thrive better in biodiverse settings rather than requiring the chemical additives mono-crops need to grow (see Delcore 2000, 2004).

Delcore (2004, p. 37) describes integrated agriculture as follows:

In Thai NGO circles, integrated agriculture refers to the intensive and diversified cultivation of a limited area of land with environmentally friendly methods and reliance on domestic labor. The goals of the method include decreasing land under cultivation (abandoned fields are ideally allowed to return to forest), use of domestic resources, avoidance of debt, and production of a variety of foods for household consumption with only a secondary emphasis on commercial production.

Mostly NGOs promote integrated agriculture as a more sustainable alternative to the agricultural intensification encouraged by both the state and multi-national corporations. Yet monks who are concerned about both the condition of the environment and the issues farmers face, especially a growing cycle of debt, seek alternative forms of agriculture as well. This investment in a crucial aspect of villagers' lives is not new among Thai monks, as there have been monks actively working on rural development and environmental issues since the 1970s.

\section{Buddhist Agriculture}

Many Thai monks undertake agricultural and community development. For example, Luang $\mathrm{Pu}$ Chan Kusalo, the founder of the Foundation for Education and Development of Rural Areas in Chiang Mai, began doing development work in support of farmers in the early 1970s. He provided farmers with knowledge, tools, and financial support necessary to change their economic circumstances and bring their lifestyles within the realm of what he considered a good (i.e., Buddhist) life (Darlington 1990, 2012, pp. 93-132).

Other monks are now going beyond this model. They are not just offering guidance and resources, but are investing themselves in the act of farming, whether directly or through running model farms. They undertake this work for multiple reasons, ranging from protecting and preserving the forest to working to end farmers' suffering emerging from the impacts of global economic practices such as industrial and contract farming.

One such monk is Phrakhru Somkit Jaranathammo in Nan. Somkit uses agriculture as a means to support his community and promote environmentally and economically sustainable livelihoods. He

3 Dayley (2011) argues this approach taps into Thailand's agrarian myth of an idealized past. While some monks do prioritize this idealized image of self-sufficiency, many, such as Phrakhru Somkit, look for ways to meet farmers' desires for a more economically viable livelihood than subsistence farming while promoting practices framed by Buddhist ethics. 
works with groups of villagers, building collaborative relationships and networks among them rather than focusing only on the issues of individual farmers.

Somkit's ideas emerged from several influences, including Buddhism, secular science, and his own experiences. First, he learned from other monks. Within Nan Province, the monk, Phrakhru Pitak Nanthakhun, began working with NGOs concerned with the livelihood and environmental issues facing the province. Somkit joined with Pitak in the early 1990s, learning his methods and gaining the support to undertake his own community and environmental work. Somkit was also influenced by Phrakhru Manas Natheepitak, the monk who performed the first tree ordination in 1988. Tree ordinations quickly became a symbolic ritual designed to reframe the relationship between villagers and the forest from one based on providing material resources to a consideration of spiritual interdependence (Darlington 1998, 2012). Manas observed the negative impacts of commercial farming and logging in the early 1970s as drought impacted farmers' livelihoods in his district in Phayao Province. At the request of villagers, he initiated first a long-life ceremony (suep chata) for waterways, and later rites to consecrate trees and forests, both aimed at engaging villagers and helping them understand the connections between their agricultural and livelihood methods and the condition of the natural resources on which they depend (Darlington 2012, pp. 58-61). Both monks served as models of monks who engage directly with their lay followers in order to deal with the social, economic, and environmental problems that farmers face.

Somkit pursued both religious and secular education in his efforts to help his community. While moving through levels of the Buddhist hierarchy based on his knowledge of scriptures, Somkit also completed bachelor's and master's degrees, the latter in Man and Environment Management at Chiang Mai University. Obtaining a secular scientific background enabled him to collaborate more fully with NGO and state agents as he implements his form of dhammic agriculture.

I first met Phrakhru Somkit in 1991, just as I was starting my research on the intersection of Buddhism and the environment in Thailand. Somkit was a monk in his mid-twenties, having ordained as a novice when he was 12. At the time, Somkit was just beginning his own research and experiments with integrated agriculture on the land behind the village temple where he lived.

Somkit took me to see his small farm. Initially, I did not realize we were in the farm. I thought we were still walking through woods and over-grown fields until the monk pointed out the fruit trees surrounded by pea vines and other vegetable plants. A small fish pond provided water in the middle of the farm, with chickens running freely and eating both insects and fruit remnants.

Farming is not a typical activity for a monk. The Vinaya, the rules of behavior for monks, forbids monks from digging the soil to avoid harming any life there. Generally, village monks perform rituals and give spiritual advice to the laity in exchange for material support. Villagers give donations, or dana (generosity, Pali), to monks in order to get their blessings and gain spiritual merit towards a better rebirth, or, some believe, a better situation in this life. In accepting dana, monks are acting as "fields of merit" (Hanks 1962). Their presence and their acceptance of offerings enable the laity to accrue positive merit towards a future rebirth. The monks' primary aim is to help relieve the suffering of the villagers through guiding them spiritually. Most monks are concerned about the material conditions of the villagers as well, as that can impact the degree of their efforts to make merit and to support the temple. But drawing on the distinctions between householders and renunciants, there tends to be a division of labor between the lay leaders (often former monks) and monks who live at a village temple. Lay leaders focus on material conditions of villagers' lives while the monks emphasize spiritual practice and perform rituals.

Phrakhru Somkit broadened his role due to recognition of the suffering farmers encounter from rapid economic and agricultural changes and resulting environmental degradation. The monk witnessed the impacts of government development policies that promoted contract and cash-cropping, and the rise of consumerism and its consequent tolls on the well-being of villagers' lives. He noticed that "some villagers have had negative experiences from practicing capitalist agriculture. They have bad health.... [This] agriculture has destroyed the nature on which they depend." As farmers adopted 
the new techniques and technologies of capitalist agriculture, this approach prevented "the farmers from seeing the value of the forest" (interview 6/27/2019).

At the same time, NGOs across the country were stepping up their efforts to counter the negative impact of these policies, promoting alternative agriculture (Delcore 2004) and environmental sustainability. Conditions were ripe for Somkit to step into the social arena through an area both familiar and of direct concern: agriculture. He chose to use his position as a village monk to explore and promote alternatives to the farmers' debt-ridden lifestyle resulting from contract agriculture.

To do this, Somkit runs a model integrated agriculture farm on the land behind his temple. He received the first plot outside of the temple land as a gift from his father in the mid-1990s. The land donated to him by his father was exhausted from erosion caused by cultivation of feed corn on the steep hillside combined with intensive chemical fertilizer use. After letting the land lie fallow for ten years, Somkit noted that it had once again become lush forest full of biodiversity of plants and animals. Because his father gave him land in order to make merit, people said that Somkit went on bindabat for land. Bindabat is the practice of going on alms rounds and accepting the offerings from the laity. Usually donations take the form of food and other necessities, but in this case, people began to give land to the monk for his farm (Darlington 2012, p. 157).

Receiving the land from his father pushed Somkit to recognize his responsibility to care for land. He realized that cash-cropping and contract agriculture damaged the land; because the soil was worn out, farmers could no longer productively grow crops on their land. Somkit observed the cycle of debt that farmers faced as they changed their livelihoods based on pressure from seed companies and government development policies encouraging intensive, market-based agriculture. As he watched the land his father donated to him recover gradually, he understood the complicated relationship of land and farmers. Farmers need healthy land, which requires care and mindfulness in how the land is used. Healthy land contains biodiversity with numerous plants and animals interacting and supporting each other. Somkit begin to experiment with integrated agriculture on the land behind his temple.

Accepting land as donations and putting it to use in order to relieve the suffering of farmers forms a new activity for a village monk. Somkit's father no doubt received merit for his donation of land-the fact that villagers referred to such donations as a response to Somkit's bindabat rounds indicates the reciprocal exchange involved in merit making. Somkit remained a "field of merit" for the villagers, enabling them to make merit and spiritual progress through donations. The form of the donations and what the monk did with those donations did not follow the customary practices, however. Somkit, as other engaged Buddhists, expanded the concept of the monk's responsibility to relieve suffering to include actively working towards improving the villagers' livelihoods and the state of the natural environment, particularly the forest, in which they live.

Such interpretations of a monk's role create controversies as well as positive change. Critics of engaged Buddhism often see such emphasis on modern problems as inappropriate for renunciants who should focus on achieving Awakening. Others argue that concepts of Buddhist environmentalism are an anachronistic application of ecological ideas into Buddhist teachings (Harris 1991; Pedersen 1995). While engaged Buddhists remain a minority in the Buddhist world, their interpretations of how to apply Buddhist principles to contemporary suffering have gained increasing acceptance (King 2005, 2012; Queen 1996). In Thailand, activist monks face criticism and personal attacks on their reputation and even person because of their efforts to promote social justice. They are scrutinized closely and find they need to behave according to Buddhist norms more carefully than most monks (Darlington 2012, pp. 197-221).

Somkit started his farm as the economy was changing in Thailand. The government had been promoting economic development based on industrial and export agriculture since the 1960s. Farmers in Nan Province, being one of the more remote areas of the nation, only began to shift from subsistence and limited market-based agriculture to more intensive cash-cropping in the 1980s, after the end of the Communist insurgency in the region. Somkit's father was among the first in his village to give up subsistence farming in the mountainous uplands to begin growing feed corn. 
The shift to cash-cropping and intensive mono-crop agriculture did not prove as fruitful for small farmers as they expected. For many farmers across Thailand, the push for agricultural development and industrialization resulted in debt and environmental degradation, and consequent social problems. Somkit's own family shifted from primarily growing food for subsistence on the steep hillsides of Nan Province to engaging cash-cropping in the early 1980s. They sought to improve their lives, seeking to participate in the benefits they saw in the modern, material world. They were encouraged by the government's promotion of agricultural development that they believed would bring them from a backwards lifestyle into modernity and comfort. The reality was different as the crops often did not meet the high standards of the companies, and farmers went into debt. They expanded their fields through clear-cutting more forest to try to make ends meet.

Somkit established an integrated agriculture farm to show the villagers an alternative to contract farming. He involved villagers in his farm so that they could see the effectiveness of integrated agriculture. Initially, he invited local kids to the farm, showing them methods and values of integrated farming and the value of nature through Dhamma walks into the forest. He taught the children how to plant trees and take care of them.

The kids took their new knowledge and experiences home and told their parents what the monk was doing on his farm. Gradually family members begin to engage as well. Somkit supported the families with seedlings and baby animals and fish stock from his farm. The success of his farm served to inspire villagers to emulate his practices.

Somkit informed me in an interview in June 2019 that these activities formed the first of three stages of his activism. The first stage, "twenty to thirty years ago when we started to experience problems [of deforestation], the idea was to preserve the forest." Yet, these efforts did not account for all the costs for farmers to engage in alternative or integrated agriculture without alternative sources of income. In the second stage, "given the technological investments [required for agricultural production], people became more indebted. In order to fight against indebtedness, we created different savings funds. Still, we couldn't stop the debt" (6/27/2019).

The increase of technological and material goods in society exacerbated rural debt. People became addicted to convenience, the monk argued. He encouraged people to live simple lives, not to depend on material things for comfort. Preaching simplicity, however, "is like using a small piece of wood to ward off a large log," he told me. "It is like we are using a small idea to fight the very big idea of capitalism" (interview 6/27/2019). Somkit realized he needed something more effective that would show people how to transform their thinking as well as their actions.

Somkit refers to the new approach he adopted as dhammic agriculture. Dhammic agriculture goes beyond subsistence farming. In the initial phases of his activism, he encouraged farmers to produce enough to eat and sell only the excess. "This idea is outdated," he claims, as it does not enable farmers to improve their lives or truly get out of debt. Instead, he now focuses on income generation through effective means. People should "grow less but gain more produce." To do this, farmers should "focus on quality so that consumers are willing to buy our products and they can consume our produce with dignity" (interview 6/27/2019).

The monk says he is now working with approximately 50 farmers in an agricultural cooperative. The farmers support each other as they shift from contract agriculture to dhammic agriculture. Somkit demonstrates in his model farm a method of intensive planting that uses a small plot of land to produce quality crops for the market. This method incorporates vertical space through trellises surrounding fish ponds that hold fish and water plants and provide nourishment for all the crops. The cooperative, through the monk's efforts, works with a market in Bangkok that collects their produce and transports it to the capital. Crops such as a local squash-not the conventional, hybrid type promoted by agro-chemical companies-not found in central Thailand have become popular in the Bangkok market, giving the farmers greater income. In the process, Somkit puts more effort into "promoting production and management and marketing" of produce rather than simple self-sufficiency (interview 6/27/2019). 
The income farmers gain from this intensive, quality-driven approach exceeds what they were making through either contract or cash-cropping or sufficiency-based integrated agriculture.

In this way, Somkit would probably agree with Dayley's critique that "the agrarian myth is not progressive but inhibits farmer autonomy and disparages developments in agricultural science, production technology, and market exchange" (Dayley 2011, p. 342). Somkit is not trying to return to a past ideal (the "agrarian myth") but support farmers in making a good income based on their knowledge and observations coupled with enacting Buddhist principles. In particular, he emphasizes the four virtues the Buddha taught for householders. Through combining Buddhist values, scientific knowledge, and economic market strategies, Somkit promotes dhammic agriculture as a means of giving farmers more agency while caring for the forest.

A major challenge facing farmers in Nan is the lack of land title. The government created around $80 \%$ of the province as protected land, including national parks and national preservation forests. Only about $14 \%$ of the province's population owns their land (Phimonphan 2018). Farmers plant maize illegally on remote mountainsides for two key reasons: Maize grows quickly and does not require long-term investment, thereby reducing farmers' losses should they be pushed off the land; and the price of maize is high. Without land title, farmers feel no responsibility for caring for the forest as they seek their livelihood.

One aspect of Somkit's efforts to promote dhammic agriculture included inviting the then-minister of natural resources and the environment to participate in a seminar on the forest held at his temple. The monk succeeded in getting the minister to declare farmers in the district as responsible for maintaining the forest. Based on his concept of Right Livelihood, Somkit created dhammic agriculture as a means to care for the well-being of both the forest and the farmers. His method of intensive agriculture and collective marketing facilitates farmers to earn a decent living from a small plot of land. With the support of the Ministry of Natural Resources and the Environment giving them permission legally to establish small farms in the forest, many local farmers are embracing this new approach.

\section{Spiritual Ecology in Practice}

Together, the Buddhist and secular knowledges he taps enables Phrakhru Somkit to structure his relationship with the surrounding community. His work forms a new Buddhist approach to relieving suffering, of people and of nature. Dhammic agriculture, for Phrakhru Somkit, does more than relieve immediate suffering of individual farmers. He is enacting a form of what he sees as economic and environmental justice, following the moral ethics taught by the Buddha.

This case is an example of the ways in which rural agricultural communities are impacted by social, economic, and political change, and how these changes then affect the temples and monks in the community. This process leads to innovative responses by Buddhist monks through challenging the status quo, using Buddhist and secular, especially scientific and economic, knowledges, and rethinking Buddhist practices to enable farmers to help themselves, their community, and the forest. With dhammic agriculture, the forest and the farm are integral to protecting the well-being of the natural environment and the people within it.

Funding: This research was funded in part by the Luce Initiative for Asian Studies and the Environment grant given to Hampshire College by the Luce Foundation.

Acknowledgments: The author thanks Phrakhru Somkit Jaranathammo for taking the time for our interview as well as many other meetings and conversations, Phimonphan Sakitram and Pipob Udomittipong for assistance with the research and translation checks, and the two anonymous reviewers for useful feedback.

Conflicts of Interest: The author declares no conflict of interest.

\section{References}

Baicha, Wongtui. 2016. Land use dynamics and land cover structure change in Thailand (as exemplified by mountainous Nan Province). Geography and Natural Resources 37: 87-92. [CrossRef]

Chatsumarn, Kabilsingh. 1998. Buddhism and Nature Conservation. Bangkok: Thammasat University Press. 
Darlington, Susan M. 1990. Buddhism, Morality, and Change: The Local Response to Development in Thailand. Ph.D. thesis, the University of Michigan, Ann Arbor, MI, USA.

Darlington, Susan M. 1998. The ordination of a tree: The Buddhist ecology movement in Thailand. Ethnology 37: 1-15. [CrossRef]

Darlington, Susan M. 2012. The Ordination of a Tree: The Thai Buddhist Environmental Movement. Albany: State University of New York Press.

Dayley, Robert. 2011. Thailand's Agrarian Myth and Its Proponents. Journal of Asian and African Studies 46: 342-60. [CrossRef]

Delcore, Henry D. 2000. Localizing Development: Environment, Agriculture, and Memory in Northern Thailand. Ph.D. dissertation, University of Wisconsin at Madison, Madison, WI, USA.

Delcore, Henry D. 2004. Development and the Life Story of a Thai Farmer Leader. Ethnology 43: 33-50. [CrossRef]

Forsyth, Timothy. 2006. Sustainable Livelihood Approaches and Soil Erosion Risks: Who Is to Judge? London: LSE Research Online, Available online: http://eprints.lse.ac.uk/archive/00000909 (accessed on 9 September 2019).

Forsyth, Tim, and Andrew Walker. 2008. Forest Guardians, Forest Destroyers: The Politics of Environmental Knowledge in Northern Thailand. Seattle and London: University of Washington Press.

Gottlieb, Roger S. 2006. Introduction: Religion and Ecology-What Is the Connection and Why Does It Matter? In The Oxford Handbook of Religion and Ecology. Edited by Roger S. Gottlieb. Oxford: Oxford University Press, pp. 3-21.

Hanks, Lucien M. 1962. Merit and Power in the Thai Social Order. American Anthropologist 64: 1247-61.

Harris, Ian. 1991. How Environmentalist is Buddhism? Religion 21: 101-14. [CrossRef]

Kamala, Tiyavanich. 1997. Forest Recollections: Wandering Monks in Twentieth-Century Thailand. Honolulu: University of Hawai'i Press.

Kemp, Jeremy. 1988. Seductive Mirage: The Search for the Village Community in Southeast Asia. Dordrecht: Foris Publications.

King, Sallie B. 2005. Being Benevolence: The Social Ethics of Engaged Buddhism. Honolulu: University of Hawai'i Press.

King, Sallie B. 2012. Socially Engaged Buddhism. In Buddhism in the Modern World. Edited by David L. McMahan. London: Routledge, New York: Taylor \& Francis Group, pp. 195-213.

Ling, Trevor. 1973. The Buddha: Buddhist Civilization in India and Ceylon. London: Temple Smith.

Lohmann, Larry. 1993. Land, Power and Forest Colonization in Thailand. In The Struggle for Land and the Fate of the Forests. Edited by Marcus Colchester and Larry Lohmann. Penang: The World Rainforest Movement, London: Zed Books, pp. 198-227.

Payutto, P.A. 1985. Photcananukrom Phutthasasat (Dictionary of Buddhism). Bangkok: Mahachulalongkorn Buddhist University, (In Thai and English).

Pedersen, Poul. 1995. Nature, Religion and Cultural Identity: The Religious Environmentalist Paradigm. In Asian Perceptions of Nature. Edited by Ole Bruun and Arne Kalland. Surrey: Curzon Press Ltd., pp. 258-76.

Phimonphan, Sakitram. (Chiang Mai University, Chiang Mai, Thailand and Hug Muang Nan Foundation, Nan Province, Thailand). 2018. Personal communication.

Queen, Christopher S. 1996. Introduction: The Shapes and Sources of Engaged Buddhism. In Engaged Buddhism. Edited by Christopher S. Queen and Sallie S. King. Albany: State University of New York Press, pp. 1-44.

Rigg, Jonathan. 1995. Counting the Costs: Economic Growth and Environmental Change in Thailand. In Counting the Costs: Economic Growth and Environmental Change in Thailand. Edited by Jonathan Rigg. Singapore: Institute of Southeast Asian Studies, pp. 3-24.

Shalardchai, Ramitanondh. 1984. Phii Cawnaaj. [The Spirit Lords.]. University Monograph Project, Monograph Series No. 18; Chiang Mai: The Library of Chiang Mai University. (In Thai)

Sponsel, Leslie E. 2019. Ecology and Spirituality. In The Oxford Research Encyclopedia of Religion. Edited by John Barton. New York: Oxford University Press.

Stott, Philip. 1991. Mu'ang and pa: Elite views of nature in a changing Thailand. In Thai Constructions of Knowledge. Edited by Manas Chitakasem and Andrew Turton. London: School of Oriental and African Studies, University of London, pp. 142-54.

Taylor, Jim. 1993. Forest Monks and the Nation-State: An Anthropological and Historical Study in Northeastern Thailand. Singapore: Institute for Southeast Asian Studies. 
Trébuil, Guy. 1995. Pioneer Agriculture, Green Revolution and Environmental Degradation in Thailand. In Counting the Costs: Economic Growth and Environmental Change in Thailand. Edited by Jonathan Rigg. Singapore: Institute of Southeast Asian Studies, pp. 67-89.

Trisurat, Yongyut, Hiroaki Shirakawa, and John M. Johnston. 2019. Land-Use/Land-Cover Change from Socio-Economic Drivers and Their Impact on Biodiversity in Nan Province, Thailand. Sustainability 11: 649. [CrossRef]

Tucker, Mary Evelyn, and Duncan Ryuken Williams, eds. 1997. Buddhism and Ecology: The Interconnection of Dharma and Deeds. Cambridge: Harvard University Center for the Study of World Religions Publications.

(C) 2019 by the author. Licensee MDPI, Basel, Switzerland. This article is an open access article distributed under the terms and conditions of the Creative Commons Attribution (CC BY) license (http://creativecommons.org/licenses/by/4.0/). 